\title{
MODEL OF VILLAGE HEAD ELECTION ARRANGEMENT IN VILLAGE GOVERNANCE LAW
}

\author{
Sekar Anggun Gading Pinilih \\ Faculty of Law of Universitas Diponegoro, Indonesia \\ E-mail: sekar.anggun.gp@gmail.com
}

\begin{abstract}
This study aims to examine the right model in the arrangement of village head elections after the stipulation of Law No. 6 year 2014 on Village. This research is a normative law research by laws, historical, and conceptual approach. The result shows that a direct and simultaneous election model shall be the solution for the next Village Head Election. Simultaneous election model is designed since it is philosophically considered to make efficiency of the Village Head Elections, in terms of efficiency of budget, time and effort. The principle of this policy is an attempt to create a more equitable simultaneous democratization to minimize the chances of cheating. Since if the elections were not held simultaneously, it would give chance to the outsider to involve. The simultaneous election requires a coherent policy. This coherence will produce an effective synchronization of all types of elections implementation in Indonesia.
\end{abstract}

Keywords: head of village, model, election, arrangement

\begin{abstract}
Abstrak
Penelitian ini bertujuan untuk mengkaji model yang tepat dalam pengaturan pemilihan kepala desa pasca keluarnya UU No. 6 Tahun 2014. Penelitian ini merupakan penelitian hukum normatif, dengan pendekatan perundang-undangan, sejarah, dan konseptual. Berdasarkan hasil penelitian didapatkan bahwa model pemilihan secara langsung dan serentak perlu dijadikan solusi model Pemilihan Kepala Desa pada masa mendatang. Model pemilihan secara serentak dibuat karena secara filosofi dianggap menimbulkan efisiensi penyelenggaraan Pemilihan Kepala Desa, seperti efisiensi anggaran, waktu dan tenaga. Prinsip kebijakan ini adalah berupaya melakukan demokratisasi yang lebih merata secara bersamaan, sehingga celah-celah terjadinya permainan-permainan bisa diminimalisir karena ketika pemilihan itu tidak bersamaan, maka orang luar bisa masuk. Pemilihan secara serentak ini ingin ada kebijakan yang satu padu. Penyatuan ini akan membentuk sinkronisasi penyelenggaraan semua jenis pemilu di Indonesia berjalan efektif.
\end{abstract}

Kata kunci: kepala desa, model, pemilihan, pengaturan

\section{Introduction}

According to Zakaria in Wahjudin Sumpeno, village is a group of human who live together or in particular territory which organize their administration through a set of regulations and is governed by a village head who is chosen and appointed by themselves ${ }^{1}$. Meanwhile, vil-

$\Omega$ This paper is a taken from Riset Dosen Pemula research, funded by Sumber Dana PNBP DIPA Universitas Diponegoro Number: SP DIPA-042.01.2.400898/2016, on 7 December 2015 Fiscal Year 2016.

Chandra Kusuma Putra and Ratih Nur Pratiwi, Suwondo, "Pengelolaan Alokasi Dana Desa Dalam Pemberdayaan Masyarakat Desa (Studi pada Desa Wonorejo Kecamatan Singosari Kabupaten Malang)", Jurnal Administrasi Pub- lage according to R. H. Unang Soenardjo, as written by Hanif Nurcholis, is the community unity based on custom and adat law who settled within particular territory and boundaries; shares strong emotional bonds, either due to descendants or common political, economic, social and security interests; has a self-chosen board; has certain amount of wealth and has the right to organize their domestic affairs. ${ }^{2}$

lik (JAP), Vol. 1 No. 6, 2013, Malang: Faculty of Science of Administration Universitas Brawijaya, page 1205.

2 Muhammad Khoiriza N., "Desentralisasi sebagai Upaya Pembangunan Desa secara Menyeluruh Menurut UU No. 6 Tahun 2014", Jurnal Asy-Syir'ah, Vol. 50 No. 1, June 
Constitution 1945 does not regulate Village but governs adat law community unity as stated in Article 18 B paragraph (2). Village government is held based on Law Number 32 Year 2004, specifically Chapter XI, then amended by Law Number 6 Year 2014 on Village, Article 1-95 and Article 112-122. Law Number 6 Year 2014 made Article $18 \mathrm{~B}$ paragraph (2) as the constitutional basis. ${ }^{3}$ The enactment of Law Number 6 Year 2005 is expected to bring a new paradigm in development, changes the perspective of development that economic prosperity is not always identical with city or urban areas. Instead, it must start from the village to develop Indonesia since village is the foremost part of the effort of development which is derived from community initiatives, to achieve prosperity, justice and sustainability. ${ }^{4}$ Of many issues regulated in Law Number 6 Year 2004, it is interesting to observe the village head election for this is the one's starting point who meets the requirements to be a village head. Likewise, it is the starting point for village development and governance. Village head election is a form of democracy in village. Generally democracy means the government from, by and to people. ${ }^{5}$

Village head election has been regulated in law, yet it still causes many conflicts in the implementation such as money politic practice, voters vote manipulation, even conflicts among villages. Therefore, it needs a model of village head election implementation which hopefully can minimize the negative practices in the field.

\section{Problem}

2016, Yogyakarta: Faculty of Sharia and Law UIN Sunan Kalijaga Yogyakarta, page 242.

3 Hanif Nurcholis, "Undang-Undang Nomor 6 Tahun 2014 Tentang Desa Dilihat Dari Pasal 18 B Ayat 2 UUD 1945", Jurnal Masalah-masalah Hukum, Vol. 43 No.1, January $1^{\text {st }}$ 2014, Semarang: Faculty of Law Universitas Diponegoro, page 149.

4 Amelia Sri Kusuma Dewi, Ngesti D. Prasetyo, "Interpretasi Bentuk Badan Usaha Milik Desa Menurut Undang-Undang Nomor 6 Tahun 2014 Tentang Desa", Jurnal Media Hukum, Vol. 22 No. 2, Desember 2015, Yogyakarta: Faculty of Law Universitas Muhammadiyah Yogyakarta, page 243.

5 Jimly Asshiddiqie, 2012, Hukum Tata Negara dan PilarPilar Demokrasi, Jakarta: Sinar Grafika, page 293.
Based on the afore-mentioned background, the paper discusses law arrangement model of village head election based on Law Number 6 Year 2014 on Village.

\section{Research Methods}

This is a normative law research which sets law as the structure of norm system. Norm system here means principles, norms, and rule derived from legislations. ${ }^{6}$ This research uses laws, historic and conceptual approaches. This research reviewed/analyzed secondary data, especially materials of primary law in the form of law on village head election.

\section{Discussion}

General election is a tool for implementing people's sovereignty which is held directly, publicly, freely, secretly, truthfully and fairly in Republic of Indonesia based on Pancasila and Constitution of $1945 .^{7}$ The implementation of democracy party through general election and the law system in Indonesia is as the embodiment of democracy. The implementation of general election cannot be separated from citizen, because that is citizen's constitutional rights to choose or be chosen. ${ }^{8}$ One of the form of democracy party in the lower level is village head election. It seems the model of Village Head Election in Law Number 6 Year 2014 is similar to those of general election regime, likewise, the regulation of general election for president and/or vice-president and governor election that is done directly and simultanoeusly.

The writer believes that the model of direct and simultaneous village head election is a good model to apply in the future. Simultaneous election is made because it is philosophically believed to give efficiencies such as budget,

6 Mukti Fajar dan Yulianto Achmad, 2010, Dualisme Penelitian Hukum Normatif \& Empiris, Yogyakarta, Pustaka Pelajar, page 34.

7 Dede Kurniadi, "Rancang Bangun Aplikasi Sistem Pemilihan Kepala Desa Yang Terintegrasi Dengan SMS Gateway", Jurnal Wawasan Ilmiah, Vol. 6 No.11, September 2014, Garut: LPPM AMIK Garut, page 2.

8 Hasrul Harahap, "Evaluasi Pelaksanaan Pilkada Serentak Tahun 2015", Jurnal Renaissance, Vol. 1 No. 1, May 2016, Jakarta: Prima Center Indonesia, page 17. 
time and energy efficiency since it can be done in one time to choose the head. This principle of policy tries to do fair democracy simultaneously to minimize unfair play. If it is not done so, outsiders can break in. The simultaneous election requires an integrated policy. In return, it can synchronize those things to achieve an effectiveness of all kinds of election organization.

Based on the research, the advantages of simultaneous village head election are explained as follows. Firstly, time efficiency. The main spirit of simultaneous general election, either central or regional level is election efficiency especially time efficiency, because it takes place at once.

Secondly, benefit for national interest. Besides the efficiency, the simultaneous village head election basically will give benefit for national interest. The relatively similar position in range will build a synergy in system of planning development between central and regional ones. Moreover, this type of election enables the chosen village head inauguration to be done at the same time by a mayor/regent.

Third, cost-saving. Simultaneous village head election started from the ideas to save the election budget which always seems so illogical. The high cost of the elections is also considered as starting point of corruptions done by some village heads. Accordingly, the simultaneous election will save the cost since it is conducted at the same time and charged to province or regency local goverment budget.

Fourth, more structured implementation. The simultaneous elections will make the implementation is more structured because its mechanism has been ruled structurally in village law as well as the national and regional elections.

Fifth, The changing of established democratic culture. More importantly, this new method of election will build new democratic culture to villagers. All this time, villagers used to elect village head directly with unclear mechanism/or regulations. Thus, with the structured mechanism, stages and principle are similar to national and regional elections, consequently, this culture will automatically change. The culture that initially did not use structured mechanism now applies ruled mechanism which is governed in law.

Sixth, Political stability. Since every village in any subdistrict has the same code of conduct of election, it will restrain any potential conflict. Conflict in village head elections often occur due to misinterpretation of code of conduct. Hence, local goverment set out the same code of conduct for all village which will hold head of village elections and to facilitate all of people to understand the code of conduct to avoid misinterpretation. By doing so, political stability will be reached.

Seventh, it reduces any betting or gambling which is commonly done in every village head elections years ago. Money politics is commonly found during campaign period. Yet, the Ministry Home Affairs Decree Number 112 Year 2014 on campaign implementation has ruled that campaign may be in form of: limited meetings, face to face meeting, dialogs, campaign dissemination, setting up campaign property in other place determined by election committe, and other activities which do not violate the law. It will minimize money politics because there is restriction in campaign and punishment for any candidate who breaks the rule of campaign.

Eight, benecial for the committee to organize the election. Uniformity of code of conduct made by regency or city goverment for all village will facilitate election committe in organizing village head elections. It should be noted the most important thing is the shared understanding among committees concerning about the regulations or order in election. Therefore, local goverment should socialize the new regulations in village law concerning about implementation stages of village head election.

Ninth, facilitating regency or subdistrict steering committe in directing village head election committe. Steering committe will be much assisted in directing the village head election committe for taking place at once.

Tenth, easier to goverment to control the election. Since village head elections can be done in one time, it enables regency/city gover- 
ment to do monitoring conveniently. It should consider the adequacy of supervisors to monitor the election since it takes place at the same time.

Apart from its advantages, practically there are several obstacles encountered by several regencies including: First, unclear regulation. There are several unclear things to be ruled, such as the absence of detailed rule when any candidate is not satisfied with election result, and there is no exact authorized institution to settle an election result dispute which created various problem. Law Number 6 Year 2014 stipulates that village head election disputes hall be solved by regent or mayor. This potentially will not solve the problem for it is not in accordance with village autonomy. Admission of the right of villager origin principle which acomodates as independence principle in village law is not applied in Articles. As evidence, there is a regency/city goverment intervention in set-tling the dispute which should be given to vil-lage head through discussion. Moreover, conflict potentially recurs as the election finished.

Second, By simultaneous village head election, there will be many village head officers who should be officially appointed because lots of village head's terms of office ended before simultaneous election takes place. It will influence legitimacy and local goverment performance for certain period of time.

Third, regency/city government workload increases. The election is imposed to regency/ city goverment by establishing election district committe though village election committe has been already formed. Since it is regency goverment's responsibility, the regency/city committee starts their work from all plan stages of regency/ city election, facilitating the procurement of ballots until evaluating and reporting the election process.

Beides, there is another obstacle affecting village head election. It is stipulation of Constitutional Court Decree Number 128/PUUXII/2015, which examines Article 33 section g and Article 50 section (1) c Law Number 6 year 2014, since those articles contradict with Art- icle 28C section (2) Constitution 1945. Those articles oblige the candidate must live at least one year in the village and village officer is required a high school graduate. Those two requirement looks discrimintive for they block the opportunity of villagers who were lower than high school graduate to be village head candidate or village officer. Court considers that direct village head election by villagers and the hiring of villager officers must not require domicile in local village which is in accordance with the spirit of Article $28 \mathrm{C}$ section (2) constitution 1945.

Village status in village law is even reemphasized as inseparable part from local goverment organization structure. Village regulation product is also emphasized as a part of regulation law which runs the goverment function. It means, village becomes the lowest part of goverment functions legally. Therefore, the village head election and officers should not be restricted by requirement of being registered as resident and living at least one year before election registration. For court, this reason is in line with local goverment regime in order to choose village head and deputy village head that do not give requirements about domicile or residing in local area.

The writer thinks that this matter will eliminate institutional design of village recognition as it is mandated by Indonesian constitution. Recognition means to recognize and respect identity, mores, institution, and local wisdom as the form of action for cultural justice. Based on constitution's mandate, either state, private parties, economic agents, or third parties must recognize and respect the existence of village as adat law community. In this case, the existence of village covers the origin right of region either it is ascribed or developing local initiative, government, regulation or local institution, local institutions, cultural identity, the unity of society, village initiative, and village resources.

That Constitutional Court's decision enables those who do not originally come from the village to be village head. The village will be built by those who do not know the condition of 
the village well. Recognition principle cannot be separated from subsidiarity principle. Subsidiarity principle gives authority to the village to regulate, organize, and manage village problems in local way. By this principle, the village can determine direction and policy of its development by its own plan. Regarding those two principles, village-based development becomes the most crucial thing. Nowadays village is not merely representative of state in regulating the development authoritatively; it is not only as catalyst of government's projects either from Ministry/Institution, Regional Government, or even foreign aids. The governmental system in village is implemented under the direction of head village who represents society in order to build good relationship both internally and externally; ${ }^{9}$ therefore, the prospective village heads who know the condition of village well and have good relationship with society are required. If the position of village head is held by those who do not fulfill the requirements, the development of village is hard to be conducted. Identity and local wisdom of the village will be difficult to be maintained since they are not held by local people.

By not fully focusing on the existing weaknesses, the model of direct and simultaneous Village Head Election will accommodate several improvement of village governance. Besides, it aims to avoid or minimalize the negative factors in its implementation by considering the implementation of previous Village Head Elections. For the next, it is expected that Law Number 6 Year 2014 keeps maintaining the model of Village Head Election which is conducted simultaneously by rearranging several substances like regulating educational requirement for prospective village heads.

The prospective village heads are required to have educational background at least Junior High School and/or equivalent. However, the educational requirement for prospective vil-

Gusti Predi Natakusuma, "Partisipasi Politik Masyarakat Dalam Pemilihan Kepala Desa Pasca Pembentukan Desa Sungai Raya Dalam Kecamatan Sungai Raya Kabupaten Kubu Raya”, Jurnal S-1 Ilmu Pemerintahan, Vol. 4 No. 4, December 2015, West Borneo: Social and Political Sciences Faculty of Universitas Tanjungpura, page 2. lage heads should be minimally Senior High School and/or equivalence in order to be consistent with ideal law political direction in the Preamble of Indonesian Constitution of 1945 which aims to educate the life of people. It is further explained in Article 31 Section 2 of Indonesian Constitution of 1945 which states that every citizen has the obligation to undertake basic education for twelve years. ${ }^{10}$ Village head who has higher educational background can conduct the development of village by utilizing his or her potentials. Therefore, he or she can enhance the prosperity of the village as an effort to eradicate poverty in the village.

Besides, the mechanism of dispute settlement needs to be regulated. There is no detailed regulation yet if there are candidates who are unsatisfied with the result of the Village Head Election; moreover, there is no specific institution that handles the conflict in Village Head Election. In Ministerial Regulation of Home Affairs Number 112 Year 2014, it has been regulated that if the dispute in an election happens, it can be reported to Regent, then Regent will make decision for the problem. However, village head is supposed to be a central in political context; hence, dispute settlement of Village Head Election cannot be handed over to the executive or the independent team. There must be specific institution that will be given an authority to handle the conflict.

Regional Regulation particularly Regent Regulation as the executor of Regional Regulation is necessarily composed to carefully regulate the simultaneous Village head election. For example, in General Explanation of Village Law, it explains that simultaneous Village head election considers the number of villages and financial capability imposed to Regional Government Budget of regency/city, so the implementation is probably done through several phases. As the result of this policy implementation, there will be Village Head who resigns before the tenure of office is expired. Therefore, in Regional Reg-

\footnotetext{
10 Retno Saraswati, "Arah Politik Hukum Pengaturan Desa Ke Depan (lus Constituendum)", Jurnal Masalah-masalah Hukum, Jilid 43 No. 3, July 2014, Semarang: Law Faculty of Universitas Diponegoro, page 316-317.
} 
ulation, there must be a regulation concerning compensation of Village Head who resigns or dismissed before the tenure of office is expired. If there is no such regulation, the potential problems may arises.

\section{Conclusion}

The Model of Village Head Election in Law Number 6 Year 2014 is done simultaneously or through several phases. Simultaneous means that Village Head Election is conducted on the same day in all villages of Regency/City by considering the number of villages and financial capability. On the other hand, it is done through several phases in order to harmonize the office tenure of village heads by grouping the expired tenure office of Village Heads in Regency/City; thus, in the future it will be harmonious. This kind of election model is recommended to be the solution of the next Village Head Election model since it can accommodate several improvements of village governance. Moreover, it can avoid or minimize negative factors in its implementation by considering the implementation of previous Village Head Election. Besides, there will be many advantages instead of disadvantages if this kind of simultaneous election is implemented.

\section{Suggestion}

Simultaneous Village head election is a new concept. Therefore, two basic tools are required namely clear regulation regarding the process and clear regulation and institution for coping with any potential problems in the end of the process. In simultaneous Village head election, money politics is somewhat inevitable. There are no practitioners such as NGO and any related parties that have prepared themselves to conduct massive control. It will be better if the government prepares the regulation starting from the implementation until the result before simultaneous Village head election is conducted. Hence, simultaneous Village head election will run smoothly as planned.

\section{References}

Asshiddiqie, Jimly. 2012. Hukum Tata Negara dan Pilar-Pilar Demokrasi. Jakarta: Sinar Grafika;
Dewi, Amelia Sri Kusuma and Ngesti D Prasetyo. "Interpretasi Bentuk Badan Usaha Milik Desa Menurut Undang-Undang Nomor 6 Tahun 2014 Tentang Desa”. Jurnal Media Hukum. Vol. 22 No.2. December 2015. Yogyakarta: Faculty of Law, Universitas Muhammadiyah Yogyakarta;

Fajar, Mukti and Yulianto Achmad. 2010. Dualisme Penelitian Hukum Normatif \& Empiris. Yogyakarta. Pustaka Pelajar;

Harahap, Hasrul. "Evaluasi Pelaksanaan Pilkada Serentak Tahun 2015". Jurnal Renaissance. Vol. 1 No. 1. May 2016. Jakarta: Prima Center Indonesia;

Kurniadi, Dede. "Rancang Bangun Aplikasi Sistem Pemilihan Kepala Desa Yang Terintegrasi Dengan SMS Gateway". Jurnal Wawasan Ilmiah. Vol. 6 No 11. September 2014. Garut: LPPM AMIK Garut;

$\mathrm{N}$, Muhammad Khoiriza. "Desentralisasi sebagai Upaya Pembangunan Desa secara Menyeluruh Menurut UU No. 6 Tahun 2014". Jurnal Asy-Syir'ah. Vol. 50 No. 1. June 2016. Yogyakarta: Faculty of Shariah and Law of UIN Sunan Kalijaga Yogyakarta;

Natakusuma, Gusti Predi. "Partisipasi Politik Masyarakat Dalam Pemilihan Kepala Desa Pasca Pembentukan Desa Sungai Raya Dalam Kecamatan Sungai Raya Kabupaten Kubu Raya". Jurnal S-1 Ilmu Pemerintahan. Vol. 4 No. 4. December 2015. West Kalimantan: Faculty of Social and Political Science of Universitas Tanjungpura;

Nurcholis, Hanif. "Undang-Undang Nomor 6 Tahun 2014 Tentang Desa Dilihat Dari Pasal 18 B Ayat 2 UUD 1945". Jurnal Masalahmasalah Hukum. Jilid 43 No. 1. 1 January 2014. Semarang: Faculty of Law of Universitas Diponegoro;

Putra, Chandra Kusuma Ratih Nur Pratiwi and Suwondo. "Pengelolaan Alokasi Dana Desa Dalam Pemberdayaan Masyarakat Desa (Studi pada Desa Wonorejo Kecamatan Singosari Kabupaten Malang)". Jurnal Administrasi Publik (JAP). Vol. 1 No. 6. 2013. Malang: Faculty of Administration Science of Universitas Brawijaya;

Saraswati, Retno. "Arah Politik Hukum Pengaturan Desa Ke Depan (lus Constituendum)". Jurnal Masalah-masalah Hukum. Vol. 43 No. 3. July 2014. Semarang: Faculty of Law of Universitas Diponegoro. 